\title{
IDENTIFICATION OF CCR5 $\triangle 32$ ALLELE IN DIFFERENT ETHNIC GROUPS OF NEPAL
}

\author{
Shrestha $D,{ }^{1}$ Shrestha $R,{ }^{2}$ Sherchand SP, ${ }^{3}$ Sherchan $S,{ }^{4}$ Hendriksen $R S,{ }^{5}$ Bhatta- \\ Sharma $L^{6}{ }^{6}$ Bhatta $D R^{1}$
}

${ }^{1}$ Central Department of Microbiology, Tribhuvan University, Kritipur, Kathmandu, Nepal, ${ }^{2}$ Deurali-Janata Pharmaceuticals P. Ltd., Kathmandu, Nepal, ${ }^{3}$ Department of Microbiology, Immunology \& Parasitology, Louisiana State University Health Sciences Center, New Orleans, USA, ${ }^{4}$ Global Environmental Health Sciences, Tulane University, New Orleans, LA, USA, ${ }^{5}$ National Food Institute, Technical University of Denmark, Kemitorvet, Denmark, ${ }^{6}$ Saint Xavier's College, Tribhuvan University, Maitighar, Kathmandu, Nepal

\section{ABSTRACT}

The chemokine receptor CCR5 exhibits an important role for the CD-4 mediated entry of HIV-1. Previous studies revealed that $\Delta 32$ mutation on the CCR5 gene results in truncated protein and hence confers protection against HIV-1 infection and AIDS progression, as observed in Caucasian population. However, the status of $\Delta 32$ mutation on CCR5 is still unknown in many Nepali ethnic groups though detection of heterozygous CCR5 $\Delta 32$ mutation allele has been reported from Chidimar and Thakali ethnic groups. We studied the presence of the $\Delta 32$ mutation in 300 blood samples from 11 ethnic groups of Nepal by analyzing PCR product of CCR5 gene region flanking the $\Delta 32$ mutation region. The primer set (forward -5' CTC CCA GGA ATC ATC TTT ACC 3' and reverse - 5' TCA TTT CGA CAC CGA AGC AG 3') flanks the site of the $\Delta 32$ deletion region of CCR5 gene. This results in a PCR fragment of 200 base pairs for the CCR5 wild allele and 168 base pairs for a $\Delta 32$ deletion mutation allele. All samples were found to exhibit wild type CCR5 gene; but no $\Delta 32$ mutation observed. Absence of $\Delta 32$ mutation in CCR5 gene indicates that Nepali population is not genetically resistant to HIV infection, if other genes are not considered.

\section{KEYWORDS}

CCR5 $\Delta 32$, HIV, AIDS, ethnic groups, Nepal

\section{CORRESPONDING AUTHOR}

Dr. Dipendra Shrestha,

Central Department of Microbiology, Tribhuvan

University, Kritipur, Kathmandu, Nepal

Email:dipsnepal@gmail.com

Orcid ID: https://orcid.org/0000-0002-8855-1389

DOI: https://doi.org/10.3126/nmcj.v22i3.32643 


\section{INTRODUCTION}

Chemokines and chemokine receptors are important molecules for trafficking and/or effector mechanisms of leukocyte populations of human body. ${ }^{1}$ Human CC-type chemokine receptor 5 (CCR5) is a G-protein-coupled receptor family consisting 352 amino acids and is folded into seven membrane-spanning domains connected by three extracellular and intracellular loops. It is found predominantly on the cell surface of certain leukocytes e.g. T cells, monocytes and macrophages.1,2 CCR5 is the main co-receptor used by macrophagetropic strains of human immunodeficiency virus type 1 (HIV-1) and HIV-2 during viral entry to the host cell. Hence, CCR5 is an important receptor for HIV pathogenesis. ${ }^{1}$ In addition to the wild type, a CCR5 allele with a 32 base pair deletion (CCR5 $\Delta 32$ ) in the coding region is prevalent. CCR5 $\Delta 32$ is frequent in populations of European origin, and encodes a nonfunctional truncated protein that is not transported to the cell surface. Homozygotes for the $\Delta 32$ allele exhibit a strong, although incomplete, resistance to HIV infection, whereas heterozygotes display delayed progression to acquired immunodeficiency syndrome (AIDS). ${ }^{3}$ The detection of heterozygous CCR5 $\Delta 32$ has been reported in Chidimar and Thakali ethnic groups of Nepal but homozygous CCR5 $\Delta 32$ mutation allele has not been reported yet in any ethnic groups of Nepal. ${ }^{4} \mathrm{X} 4$-tropic strains of HIV-1, utilizing CXCR4 as co-receptor, arise mostly in later stages of AIDS and hence the protective effect of the homozygous deletion is not entire. ${ }^{4}$ The defective receptor variant CCR5 $\Delta 32$ grants immunological advantage against HIV pathogenesis but possess some detrimental effects in other inflammatory diseases; such as, in case of infection with West Nile virus, where CCR5- $\Delta 32$ homozygosity is associated with a significantly higher risk for fatal outcome. ${ }^{5,6}$

CCR5 $\Delta 32$ is predominantly found in European populations and displays a frequency decline from Northern to Southeastern Eurasia, with no or rare occurrences in Asians and native populations from Africa, the Americas and Oceania. ${ }^{78}$ Even in a single unit of Europe, in France, the mutation is observed more frequent in the north $(11.2 \%)$ than in the south $(6.3 \%)$; this differentiation corresponds probably to a gradient of decreasing frequencies of the $\Delta 32$ mutation in Europe from north to south. ${ }^{9}$ Based on intra-haplotypic variation determined by flanking microsatellites, it has been estimated that the first CCR $5 \Delta 32$ mutation occurred about 4000 years ago. ${ }^{10}$ Research suggests that a positive selection process for CCR5 $\Delta 32$ should have occurred in northern Europe thousands of years ago, after the Ashkenazi Jews separated from their Sephardi kin and moved to north Europe. ${ }^{11}$ The frequency of the mutation in the Lebanese population is consistent with that in the origin of the mutation in northern Europe whereas absent from African and other Asian countries. ${ }^{12-16}$ This could be attributed to a gene flow into the Middle East from northern Europe along with migration of Caucasian population downwards.

This study aims to identify CCR5 $\Delta 32$ mutation in Nepali population by using polymerase chain reaction (PCR) for the flanking region of $\triangle 32$ mutation region of CCR 5 gene. National population and housing census-2011 of Nepal exhibited 126 caste/ethnic groups out of 26,494,504 populations in Nepal. ${ }^{17}$ This showed high diversity of Nepali population, and hence the higher chance of genetic variability. We, therefore, studied the presence of CCR5 $\Delta 32$ mutation allele in Nepali population. The technique used was gel electrophoresis of PCR product which flanks the $\Delta 32$ mutation region of CCR5 gene.

\section{MATERIALS AND METHODS}

The samples in the study comprised of 300 Nepali population from 11 different ethnic groups of Nepal. The ethnic groups include Brahmin $(\mathrm{n}=40)$, Chaudhary $(\mathrm{n}=64)$, Chhetri $(\mathrm{n}=30)$, Chidimar $(\mathrm{n}=48)$, Dalit $(\mathrm{n}=10)$, Gurung $(\mathrm{n}=12), \operatorname{Kirat}(\mathrm{n}=11), \operatorname{Magar}(\mathrm{n}=10), \operatorname{Newar}(\mathrm{n}=49)$, Tamang $(\mathrm{n}=17)$ and Sherpa $(\mathrm{n}=9)$. Samples were collected and processed in 2018. The sample collection site ranges from low altitude; Nepalgunj (150 m from sea level) to high level altitude Lukla (2860 $\mathrm{m}$ from sea level) and some middle level altitudes viz Bardiya, Chitwan and Kathmandu. Sample donors are made sure they belong to decedent from homogenous parent upto three generations in terms of their ethnicity based on verbal conversation.

One milliliter of blood was collected from each of participant by utilizing aseptic technique into EDTA vials. The blood samples were collected with the help of certified laboratory technician in Pasang Lhamu Memorial Hospital, Lukla; Grande International Hospital and Kantipur General Hospital, Kathmandu; Balkumari College Medical Microbiology Laboratory, Chitwan and Nepalgunj Medical College, Banke. The collected samples were transported to Kathmandu in ice pack at $-4^{\circ}$ $\mathrm{C}$ in the soonest convenience and stored at National College Laboratory, Kathmandu at 
the same temperature. Ethical approval was received from Nepal Health Research Council (Regd no. 311/2018). In addition, written consent was taken from each subject prior to sample collection for sample collection and data publication.

DNA was extracted from the blood samples using Qiagen Reagent (Qiagen Inc., USA). The DNA extract was observed for absorbance using UV spectrophotometer (EPOCH 2, Biotek Instruments Inc. USA) and the extract with the OD ratio of 1.7-2.0 for absorbance value at $260 \mathrm{~nm} / 280 \mathrm{~nm}$ was considered acceptable quality for down-stream analysis and stored at $-20^{\circ} \mathrm{C}$ until the use. The specific region of CCR5 gene was amplified by PCR assay (Takara Holdings Inc., Japan) with primer set: forward -5' CTC CCA GGA ATC ATC TTT ACC 3' and reverse - 5' TCA TTT CGA CAC CGA AGC AG 3' (Tag Copenhagen A/S, Denmark). The primer set flanks the site of the $\Delta 32$ deletion region of CCR5 gene. This results in a PCR fragment of 200 base pairs for the CCR5 wild allele and 168 base pairs (bp) for a $\Delta 32$ deletion mutation allele. ${ }^{12}$ PCR thermal cycler was set for 32 cycles at $94^{\circ} \mathrm{C}$ for 30 seconds, annealing at $60^{\circ} \mathrm{C}$ for 30 seconds, extension at $72^{\circ} \mathrm{C}$ for 45 seconds and final extension at $72^{\circ} \mathrm{C}$ for 5 minutes.

Screening of PCR products was performed by gel electrophoresis technique. $5 \mu$ PCR product of each sample was loaded onto 3\% agarose gel along with DNA ladder of $50 \mathrm{bp}$ reference. The gel was run in electric field of $50 \mathrm{~V}$ for 30 minutes. DNA bands were stained with Ethidium bromide (EtBr) and visualized under ultraviolet radiation by gel documentation system (CSLMicrodoc Sytem, Cleaver Scientific Ltd., USA).

\section{RESULTS}

A total of 300 blood samples from 10 Nepali ethnic groups were analyzed. The samples comprised 64 Chaudhary, 49 Newar, 48 Chidimar, 40 Bhramin, 30 Chhetri, 17 Tamang, 12 Gurung,
11 Kirat, 10 Dalit, 10 Magar and 9 Sherpa. All samples exhibited presence of DNA analyzed by UV spectrophotometer at $260 \mathrm{~nm}$ and 280 nm after DNA extraction from Qiagen reagent. The DNA extract with OD ratio between 1.7 and 2.0 for absorbance value at $260 \mathrm{~nm} / 280 \mathrm{~nm}$ was considered acceptable quality for down-stream analysis.

Those DNA extracts were all amplified to primer set (forward - 5' CTC CCA GGA ATC ATC TTT ACC 3' and reverse - 5' TCA TTT CGA CAC CGA AGC AG 3'). All PCR products showed bands at 200 base pairs (bp), but none showed DNA fragments for $168 \mathrm{bp}$. This indicates that all samples processed consisted of only wild type CCR5 gene and none was homozygous or heterozygous for CCR5 $\Delta 32$ mutation allele.

\section{DISCUSSION}

The $\Delta 32$ mutation in chemokine receptor CCR5 results truncated and non-functional protein variant of CCR5. ${ }^{3}$ The allele was discovered for its resistivity against HIV-1 infection. ${ }^{3}$ Previously, the mutation has been observed frequent in European descent ${ }^{7,8}$ with the highest in Northern Europe, ${ }^{9}$ declining towards Southern Europe. ${ }^{9}$ Lucotte G, 2002, observed the gradual decline in CCR $5 \Delta 32$ frequencies from North to South latitude in Europe and beyond; and concluded that the mutation originates in the north of Europe, and disseminates towards the south during historical times. ${ }^{14}$ The CCR5 $\Delta 32$ mutation was frequently found in Northern European countries; Finland (31.63\%), ${ }^{10}$ Sweden $\quad(25.49 \%),{ }^{10}$ Norway $(21.00 \%),{ }^{10}$ Lithuania $(22.26 \%),{ }^{10}$ Russia $(24.43 \%)^{15}$ and Denmark (22.59\%); ${ }^{16}$ decreasing in Central Europe; Britain (21.20\%), Germany (19.19\%), ${ }^{16}$ Belgium (21.61\%), ${ }^{18}$ France $(16.66 \%),{ }^{19}$ Switzerland $(15.62 \%)^{18}$ and Hungary (15.15\%). ${ }^{10}$ In Southern Europe, the least frequency of CCR5 $\Delta 32$ mutation among European countries was observed, viz. Portugal (10.48\%), ${ }^{18}$ Spain

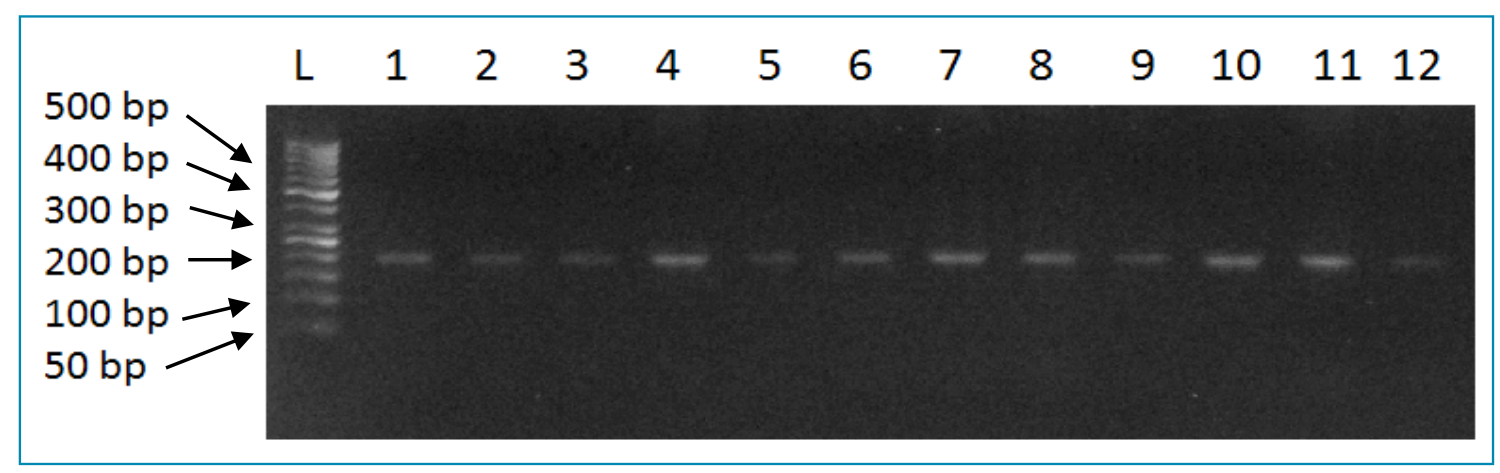

Fig. 1: PCR product of CCR5 gene, bp : base pairs, Lane L : Ladder of $50 \mathrm{bp}$, Lane 1-12: $200 \mathrm{bp}$ (wild type) 
$(6.27 \%),{ }^{20}$ Greece (8.39\%) ${ }^{21}$ and Cyprus (5.68\%). ${ }^{22}$ Few heterogeneous CCR5 $\Delta 32$ mutation, but no homogenous allele, has been reported from some Asian, American and African countries, viz. Thailand $(0.0035 \%),{ }^{23}$ Senegal $(1.43 \%),{ }^{24}$ Jamaica $(2.06 \%),{ }^{25}$ Tunisia $(2.06 \%),{ }^{26}$ Pakistan $(2.31 \%),{ }^{27}$ Argentina (2.38\%), ${ }^{28}$ Lebanon (2.39\%), ${ }^{12}$ Syria (2.83\%), ${ }^{15}$ Bangladesh (3.03\%), ${ }^{19}$ Korea (4.44\%) ${ }^{19}$ and Colombia (4.58\%). ${ }^{29}$

Studies have shown that the CCR5 $\Delta 32$ mutation allele was entirely absent from our neighboring countries; China ${ }^{30-32}$ and India. ${ }^{32}$ Similar report has been published for Japan, ${ }^{33}$ Ethiopia, ${ }^{34}$ Cameroon, ${ }^{35}$ Vietnam $^{32}$ and Uganda. ${ }^{32}$ In this study, too, 300 samples studied from 11 ethnic groups of Nepal was found to have neither heterogeneous nor homogenous allele of CCR5 $\Delta 32$. On the contrary, in 2014, Singh reported the heterozygous CCR5 $\Delta 32$ mutation allele from 6 out of 35 Chidimar samples and 3 out of 91 Thakali samples. ${ }^{4}$ The reason why discrepancy occurred remains to be explored in days to come.

Samples from countries with a high percentage of inhabitants of European descent, especially from Middle and South American countries, but also from South Africa, display higher CCR5 $\Delta 32$ allele frequencies than expected from the overall spatial distribution pattern. ${ }^{19}$ Muxel SM et al, 2008, studied the presence of $\Delta 32$ deletion from CCR5 gene in Caucasians, African and Asian ancestry in Brazil and observed that the allele is present only from Caucasians origin but not from African and Asian Ancestry. ${ }^{36}$ Lucotte has postulated in 2002 that the mutation originates in the north of Europe, and disseminates towards the south during historical times, ${ }^{14}$ and that the descendants of European origin can only exhibit the mutation allele. ${ }^{36}$ On this basis, for any Nepali population to exhibit the mutation, the genotype of European ancestor must have to be incorporated at least at any one point of their ancestral history. Chidimar ethnic group is a small ethnic group of Nepal included in Terai Dalit confined in Farwestern Terai region of Nepal with population of 1,254 and Thakali ethnic group comprises 13,215 populations according to National Population and Housing Census 2011. Both of these ethnic groups bear cultural characteristics to marry among own ethnic group. So, further analysis seems necessary to confirm the existence of $\Delta 32$ mutation in CCR5 gene of both of the ethnic groups as reported by Singh in 2014. The further analysis may be gene sequencing of the CCR5 gene of the ethnic groups or other highly sophisticated molecular technologies.

Lack of sequencing data is one of the caveats of this study. Presence or absence of $\Delta 32$ mutation in CCR5 gene might not be enough itself to exhibit significant role in the activity of the CCR5 protein, which we could not cover. Absence of $\Delta 32$ deletion in CCR5 gene from studied population does not necessarily mean it might not be present in Nepal. Further study with more sample size and ethnic groups could be more useful. Absence of CCR $\Delta 32$ mutation indicates that HIV susceptibility to Nepali population, if other genes are not considered, is high. The result even suggests very low or no migration of European descends to Nepal or their gene into Nepali genetic pool.

\section{ACKNOWLEDGEMENTS}

We would like to acknowledge University Grant Commission, Nepal for funding the research under PhD fellowship program and Dr. Megh Raj Banjara, Head, Central Department of Microbiology, and Dr. Dev Raj Joshi, Central Department of Microbiology, Tribhuvan University for their continuous inspiration and support in manuscript writing. We acknowledge Grande International Hospital, Kathmandu, Pasang Lhamu Memorial Hospital, Lukla, Balkumari College, Chitwan and Nepalgunj Medical College, Banke for providing their laboratory for sample collection and National College, Kathmandu for DNA extraction, performing PCR and storage, and Bir Hospital, Kathmandu for performing gel electrophoresis.

\section{REFERENCES}

1. Blanpain C, Libert F, Vassart G, Parmentier M. CCR5 and HIV infection. Receptors Channels 2002; 8: 19-31.

2. Wu L, Paxton WA, Kassam N et al. CCR5 levels and expression pattern correlate with infectability by macrophage-tropic HIV-1, in vitro. J Exp Med 1997; 185: 1681-91.

3. Liu R, Paxton WA, Choe S et al. Homozygous defect in HIV-1 co-receptor accounts for resistance of some multiply-exposed individuals to HIV-1 infection, Cell 1996; 86: 367-77.
4. Singh NB. Occurrence of CCR5 Heterozygous $32 \mathrm{bp}$ deletion in Nepali ethnic groups, J Inst Sci Technol 2014, 19: 105-8.

5. Michael NL, Nelson JA, Kewal Ramani VN et al. Exclusive and persistent use of the entry coreceptor CXCR4 by human immunodeficiency virus type 1 from a subject homozygous for CCR5 delta32.J Virol 1998; 72: 6040-7.

6. Glass WG, McDermott DH, Lim JK et al. CCR5 deficiency increases risk of symptomatic West Nile 
virus infection, J Exp Med 2006; 203: 35-40.

7. UV Sollocha, K. Lang, V. Lange, I, Böhme, AH Schmidta, J. Sautera, Frequencies of gene variant CCR5- $\triangle 32$ in 87 countries based on next-generation sequencing of 1.3 million individuals sampled from 3 national DKMS donor centers. Human Immunol 2017, 78 (11-12), 701-17.

8. Samson M, Libert F, Doranz BJ, Rucker J, Liesnard C, Farber CM et al. Resistance to HIV-1 infection in Caucasian individuals bearing mutant alleles of the CCR-5 chemokine receptor gene. Nature 1996; 382: 722-5.

9. Lucotte G, Mercier G. Frequency of the coreceptor CCR5 gene delta 32 mutation in different French regions. C R Acad Sci III 1998; 321: 409-13.

10. Libert F, Cochaux P, Beckman G et al. The CCR5 mutation conferring protection against HIV-1 in Caucasian populations has a single and recent origin in north-eastern Europe. Hum Mole Genet 1998; 7: 399-406.

11. Maayan S, Zhang L, Shinar E et al. Evidence for recent selection of the CCR5-delta 32 deletion from ifferences in its frequency between Ashkenazi and Sephardi Jews. Genes Immun 2000; 1: 358-61.

12. Karam W, Jurjus R, Khoury N et al. Frequency of the CCR5-delta 32 chemokine receptor gene mutation in the Lebanese population. East Mediterr Health J 2004; 10: 671-5.

13. Hutter G, Nowak D, Mossner M et al. Long-Term Control of HIV by CCR5 Delta32/Delta32 Stem-Cell Transplantation. N Engl J Med 2009; 360: 692-8.

14. Lucotte G. Frequencies of 32 base pair deletion of the $(\Delta 32)$ allele of the CCR5 HIV-1 co-receptor gene in Caucasians: a comparative analysis. Infect Genet Evol 2002; 1:201-5,

15. Lucotte G, Mercier G. Distributions of the CCR5 gene 32 bp deletion in Europe, I Acquir Immune Defic Syndr hum retrovirol 1998; 19:174-7.

16. Struyf F, Thoelen I, Charlier N. Prevalence of CCR5 and CCR2 HIV-co-receptor gene polymorphisms in Belgium. Hum Hered 2000; 50: 304-7.

17. National Population and Housing Census 2011 (National Report), Government of Nepal, National Planning Commission Secretariat, Central Bureau of Statistics, Kathmandu, Nepal, November, 2011

18. Ruiz-Ferrer M, Barroso N, Antiñolo G, AguilarReina J. Analysis of CCR5-Delta 32 and CCR2V64I polymorphisms in a cohort of Spanish HCV patients using real-time polymerase chain reaction and fluorescence resonance energy transfer technologies. J Viral Hepat 2004; 11: 319-23.

19. Magierowska M, Lepage $\mathrm{V}$, Boubnova L et al. Distribution of the CCR5 gene 32 base pair deletion and SDF 1-3'A variant in healthy individuals from different populations. Immunogenetics 1998; 48: 417-9.

20. Christodoulou C, Poullikas M, Neuman AU, Kostrikis LG. Low frequencies of CCR 532 allele among Greeks in Cyprus. AIDS Res Hum Retrovirus 1997; 13: 1373-4.

21. Hisada M, Lal RB, Masciotra S et al. Chemokine receptor gene polymorphisms and risk of human T lymphotropic virus type I infection in Jamaica. $J$ Infect Dis 2002; 185: 1351-4.

22. Barbouche RM,, Hong L, Dellagi K, Kostrikis LG. Contrasting frequencies of CCR 532 and CCR2-641 alleles in the Tunisian population. I Acquir Immune Defic Syndr 2001; 26: 298-301.

23. Khaliq S, Hameed A, Ayub Q et al. Frequency of CCR5 Gene 32-bp deletion in Pakistani ethnic groups. Genet Test 2002; 6: 123-7.

24. Mangano A, Theiler G, Sala L, Capucchio M, Fainboim L, Sen L. Distribution of CCR5-Delta 32 and CCR2-64I alleles in an Argentine Amerindian population. Tissue Antigens 2001; 58:.99-102.

25. Voevodin A, Samilchuk E, Dashti S. A survey for 32 nucleotide deletion in the CCR5 chemokine receptor gene (Dccr-5) conferring resistance to human immunodeficiency virus type 1 in different ethnic groups and in chimpanzees. J Med Virol 1998; 55: 147-51.

26. Franciso JD, Jorge AV, Pablo JP et al. Frequency of CCR5 Delta 32 Mutation in Human Immunodeficiency Virus (HIV) - seropositive and HIV-exposed Seronegative Individuals and in General population of Medellin, Colombia. Mem Inst Oswaldo Cruz 2000; 95: 237-42.

27. Xiao J, Hu F, Xu H et al. Provincial distribution of three HIV-1 resistant polymorphisms (CCR5Delta32, CCR2-64I, and SDF1-3' A) in China. Sci China C Life Sci 2000; 43: 16-20.

28. Martinson JJ, Chapman NH, Rees DC, Liu YT, JB Clegg. Global distribution of the CCR5 gene 32 base pair deletion. Nat Genet 1997; 16: 100-2.

29. Lu Y, Nerurkar VR, Dashwood WM et al. Genotype and allele frequency of a 32-base pair deletion mutation in the CCR5 gene in various ethnic groups: absence of mutation among Asians and Pacific Islanders. Int'l J Infect Dis 1999; 3: 186-91.

30. Su Q, Mai Z, Zang N, Wu S, Xiao X, Liang $\mathrm{H}$. Distribution of CCR5-\{delta\}32, CCR2-64I, and SDF1-3'A in Guangxi Zhuang population. J Int'l Assoc Physicians in AIDS Care (Chic) 2010; 9: 145-9.

31. Huanliang L, Nakayama E, Ioannis $\mathrm{T}$ et al. Polymorphisms in CCR5 chemokine receptor gene in Japan. Int'l J Immunogenet 2007; 34: 325-35.

32. Solloch UV, Lang K, Lange V, Böhme I, Schmidt AH, Sauter J. Frequencies of gene variant CCR $5-\Delta 32$ in 87 countries based on next-generation sequencing of 1.3 million individuals sampled from 3 national DKMS donor centers, Hum Immuno. 2017; 78: 710-7.

33. Nkenfou CN, Mekue LC, Nana CT, Kuiate JR. Distribution of CCR5-Delta32, CCR5 promoter 59029 A/G, CCR2-64I and SDF1-3'A genetic polymorphisms in HIV-1 infected and uninfected patients in the west region of Cameroon. BMC Res Notes 2013; 23: 288.

34. Ruchusatsawat N, Vongsheree S, Thaisri H, Phutiprawan T. The first report of CCR5 delta 32 mutant in Thai injecting drug users. Asian Pac J Aller Immunol 2000; 18: 93-8.

35. Kokkotou E, Philippon V, Guèye-Ndiaye A et al. Role of the CCR5 delta 32 allele in resistance to HIV-1 infection in west Africa. J Human Virol 1998; 1: 46974.

36. Muxel SM, Borelli SD, Amarante MK et al. Association study of CCR5 delta 32 polymorphism among the HLA-DRB1 Caucasian population in Northern Paraná, Brazil. J Clin Lab Anal 2008; 22: 229-33. 